\title{
Safety and risks of nuclear power: Changing the discourse (by the example of Tomsk region)
}

\author{
S.V. Negrul ${ }^{2}$, T.G. Trubchenko ${ }^{1}$, and E.Y.Lemeshko ${ }^{1 \mathrm{a}}$ \\ ${ }^{1}$ Tomsk polytechnic university, 634050 Lenina str., 30, Tomsk, Russia \\ ${ }^{2}$ Tomsk state university, 634050 Lenina str., 36, Tomsk, Russia
}

\begin{abstract}
The paper considers the peculiarities of risk perception in the discourse of the key subjects that form the platform to discuss the development of nuclear energy. The study was conducted in the region with a large nuclear enterprise. The dominant groups setting reference points of perception were revealed. The shift to a "hierarchical" model of ideology was shown. The analysis was based on the cultural theory of risk perception of M.Douglas, A.Wildavsky
\end{abstract}

\section{Introduction}

Any problem having a public response (as a problem of nuclear power) is a field of semantic interpretations which substantially depend on interests of various social groups. Today in the conditions of revival of interest in nuclear power we reconsider the results of Chernobyl accident and prospects of nuclear branch development. The objective facts and results of measurements can be perceived by public consciousness as more or less accepted from the point of view of risks and threats, there can be a shift of a public assessment of the acceptable risk level. This is the basis of revision of safety standards in the operation of potentially dangerous objects, the requirements for qualification of personnel, organization of measures to prevent emergencies.

Environmental disasters and risks, as well as the potential benefits of nuclear power development are the subject of public attention in a particular implementation of the information policy. In the 80-90s of the last century (after the accident at the Chernobyl Nuclear Power Plant) open access to various information was followed by a growth of concern of the population in environmental problems. Activization of the public sector on a wave of a radio phobia was replaced by the period of relative calm. Today it is possible to speak about a new round in the development of nuclear power against revival of this branch.

What values are replacing environmental ones? What expertise or political groups today define the trend of risk perception? In what direction does the change of a paradigm of the acceptable risks perception go? What consequences can be expected due to the changes of the identified perception paradigm? These issues are the subject of sociological research.

\section{Materials and methods}

The study is based on the author's postulates of the "cultural theory" of risk perception (M.Douglas, A.Wildavsky) [1]. According to this theory, the risks are not the only objective reality, but also a "social construct." Selective attention to the risks is associated with cultural prejudices (outlooks, ideologies), which depend on the way of life of individuals in the given society. M.Douglas, A.Wildavsky allocate three types of cultural prejudices or ideologies that protect certain models of social organization: hierarchical, egalitarian and individualistic. The issue of risk acceptability is solved politically, i.e., by means of the competition of leaders in questions of events interpretation.

Risks are designed by means of the discourses related to the competition for the dominating vision.

The interests of social actors are embodied in a certain ideology reproduced in the methods of presenting information, "myths", characteristics of the argumentation of its position and interpretation of facts. It reflects "the boundaries of acceptability" of risks. Discourse promotes the reproduction of unequal distribution of powers between social groups (Van Dijk). From a position of the social and constructivist approach the language embodied in a discourse is way of influence by means of which people change the world.

The key factors influencing both the formation of the public opinion and the acceptance of strategic solutions for development of nuclear energy, are top management of energy companies, government officials, activists of non-governmental organizations, environmental movements, representatives of the media (Figure 1).

\footnotetext{
${ }^{\mathrm{a}}$ Corresponding author: lemeshkoel $@$ tpu.ru
} 


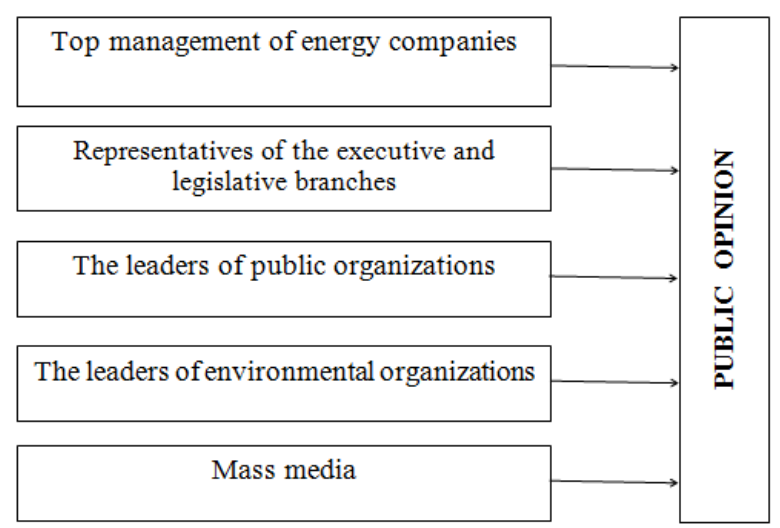

Fig. 1. Key factors influencing the formation of public opinion

This article presents an analysis of the results of several sociological surveys conducted in Tomsk and Tomsk region from 1997 to 2015.

Sociological research was conducted by a large-scale survey (formal interviews); expert interviews (interviews with heads of major enterprises of the nuclear industry, representatives of the executive and legislative authorities of the city and region, activists of public and ecological organizations, the media). In 2007, 2013, 2015 on average at least 20 representatives were interviewed among them.

Materials for analysis were the data of scientificpractical conferences held in Tomsk, such as "Modern nuclear power: benefits and risks", etc.), the regional forum-dialogue "Nuclear production, society, safety", proceedings of the round tables, interviews available for public, with key speakers on nuclear energy discussion. Materials for analysis were the transcripts of interviews and debates.

The study of discourse is based on the reconstruction of the discourse-analysis of key semantic categories used in the process of discussing some issue. Usage of the language gives a person a view of reality, which not only reflects what it is, but also constructs it.

The design of the discourse, as a rule, is considered through "articulation" in language meaningful categories. In this respect, the discourse identifies the potentials of expression, guiding agentivity of subjects, and indicates the limits of the scope of "building" and interpretation images of reality, of personality and identity [2].

The discourse analysis was based on:

- the identification of "nodal dialogue points" (the central concepts, themes, around which the discourse was organized);

- "chains of equivalence";

- identities and roles;

- concepts for the analysis of conflict [3].

\section{Results and discussion}

In the region there is the Siberian Chemical Plant (SCP) - one of the largest enterprises of the nuclear industry.
SCP is a part of Rosatom state Corporation and is located on the territory of closed company town.

In the post-Soviet period the company completed the conversion of production. Today one of the leading directions of activity of the enterprise is the disposal of liquid radioactive wastes, processing of used nuclear fuel. In this field since 1991, a partnership with French company Cogema (now Areva) was established on the import and enrichment of spent uranium.

The main activities of the SCP are: production of raw materials, enriched uranium; processing, transportation and storage of nuclear materials; production of thermal and electric energy.

The production center consists of the four plants of working with nuclear materials:

- the isotope separation plant;

- the sublimate plant;

- the radiochemical factory (closed on 29.06.2015);

- the chemical-metallurgical plant;

- CHP

- the construction site of a new NPP on the basis of the reactor "BREST-300" and a pilot plant

- for the production of fuel for this type of reactors (from April 2015). The establishment of a new plant was named the project "Breakthrough" in the press.

For the past 15 years in Tomsk region it was planned to implement several other projects, including the construction of the MOX plant (from the English. mixed-oxide fuel (MOX) - mixed fuel on the basis of oxides of $239 \mathrm{Pu}$ and $238 \mathrm{U}$ ) in 2003-2004, the nuclear power plant (2007), the Centre for nuclear medicine and the project "BREST -300" (2014), etc. These ideas were discussed in public debates. A controversial issue nowadays was the possible construction of a nuclear reactor of natural safety of fast neurons ("Breakthrough"), which, according to the developers, minimizes the production of liquid radioactive waste and eliminates the risk of radioactive accidents.

There are objective grounds for alarm. During the company's existence there was a series of radiological incidents. Five of them are classified as serious (have Level 3 on the International Nuclear Event Scale). Particularly noticeable was the accident on April 6, 1993 ("serious incident"), details of which became available to the general public.

Based on data survey analysis the tendency of perception of prospects and consequences of implementation of nuclear power projects are revealed.

It can be stated that currently there is a shift of estimates, overestimation of the significance of

environmental consequences of nuclear threats and the transition to the dominance of socio-economic priorities in the assessment of the benefits and consequences of exploitation of potentially dangerous objects. One indicator of this transition is the change of public opinion. According to sociological research, the independent research center "ROMIR" (November 2000), 93,5\% of Russians have a negative attitude towards the import into Russia of radioactive materials for storage and processing. It is known about several initiatives of citizens and their associations opposing 
import and processing of SNF, in particular: the initiative group created in Krasnoyarsk region (where construction of the plant for processing of SNF imported from abroad was planned). In 1997 they collected more than 100 thousand signatures for holding a referendum to ban the construction of RT-2 plant. Then construction was transferred to Tomsk region. A sociological survey of the population in 2007 showed the following picture: the overwhelming majority $-85 \%$ of respondents stated serious arguments against the construction of nuclear facilities. The responses - 59\% - had mainly a phobic character ("this is a fatal danger for the population" and "economic benefits from NPP is incomparable to the costs and risks") [4]. Previous studies in 1997 and 2013 [5, 6] have shown that the significance of environmental problems decreases, at the same time, there is a growing concern of population about socio-economic problems. [4]. So, during the study period, environmental concerns have shifted in importance from the 2 nd to the 12th place, giving leadership to the concerns of "growth of tariffs of housing and communal services", "roads conditions", etc.

Besides, according to research results of 2013 "the share of the respondents who positively estimate the consequences of development of the nuclear industry in the region more than twice exceeds the share of those who estimate these consequences negatively (respectively $57 \%$ to $25 \%$ )" [6].

The change of the public opinion was influenced by a number of factors, significant from which were: information policy on creation a positive image of nuclear power; undeveloped civil society, i.e. disability of certain groups of the population to defend their interests and lack of positive experience of such kind, concentration on the current problems of own survival.

In debates about nuclear power, "safety" is a key concept. However, semantic interpretations differ greatly.

There is a number of dilemmas regarding the various aspects of risk perception (Table 1).

Table 1. The dilemmas connected with perception of safety and different risks at construction and operation of objects of the nuclear industry (NI) in the territory of Tomsk and Tomsk region

\begin{tabular}{|c|c|}
\hline "Technocentric position" & $\begin{array}{l}\text { "The environment- oriented } \\
\text { position" }\end{array}$ \\
\hline \multicolumn{2}{|c|}{ The perception of the economic security and risks } \\
\hline $\begin{array}{l}\text { 1. 1.The economic impact } \\
\text { and socio-economic } \\
\text { effects; reduction of } \\
\text { capital costs (new } \\
\text { technology) }\end{array}$ & $\begin{array}{l}\text { 1.1. Economic losses (high } \\
\text { capital intensity), } \\
\text { 1.2. Costs of elimination of } \\
\text { unforeseen consequences are not } \\
\text { provided in projects }\end{array}$ \\
\hline $\begin{array}{l}\text { 1.2. Export of } \\
\text { breakthrough } \\
\text { technologies, investments } \\
\text { into the region }\end{array}$ & $\begin{array}{l}\text { 1.2. Nuclear industry - } \\
\text { "yesterday in the energy sector" }\end{array}$ \\
\hline \multicolumn{2}{|c|}{ Perception of socio-political safety and risks } \\
\hline $\begin{array}{l}\text { 2.1. The nuclear industry } \\
\text { is the benefit for the } \\
\text { region, image, the } \\
\text { political capital. }\end{array}$ & $\begin{array}{l}\text { 2.1. Narrow positioning of the } \\
\text { region } \\
\text { 2.2. Lack of public support. }\end{array}$ \\
\hline
\end{tabular}

\begin{tabular}{|c|c|}
\hline \multicolumn{2}{|c|}{ Perception of ecological safety and risks } \\
\hline $\begin{array}{l}\text { 3. 1. Nuclear energy is the } \\
\text { most environmentally } \\
\text { friendly form of energy } \\
\text { today. }\end{array}$ & $\begin{array}{l}\text { 3.1. Nowhere in the world there } \\
\text { are safe technologies of spent } \\
\text { nuclear fuel (SNF) disposal, } \\
\text { threats to the environment }\end{array}$ \\
\hline $\begin{array}{l}\text { 3.2. Spent nuclear fuel is } \\
\text { "a valuable resource" }\end{array}$ & \\
\hline \multicolumn{2}{|c|}{$\begin{array}{c}\text { Technological risks } \\
\end{array}$} \\
\hline $\begin{array}{l}\text { 4.1. Technically- } \\
\text { developed innovative } \\
\text { technologies in the } \\
\text { operation of the nuclear }\end{array}$ & $\begin{array}{l}\text { 4.1. Outdated technology of } \\
\text { utilization of spent nuclear fuel } \\
\text { (the consequences of the past } \\
\text { activities of companies) }\end{array}$ \\
\hline into the Future"). & $\begin{array}{l}\text { 4.2. Deviation from the } \\
\text { established safety requirements, } \\
\text { violation of technology }\end{array}$ \\
\hline & $\begin{array}{l}\text { 4.3. The absence of feedback } \\
\text { between designers, NPP, } \\
\text { Minatom, there is no reliance on } \\
\text { previously developed safety } \\
\text { requirements }\end{array}$ \\
\hline $\begin{array}{l}\text { 4.2. Safety - " experts' } \\
\text { business " }\end{array}$ & $\begin{array}{l}\text { 4.4. Security is provided by the } \\
\text { public control, attracting people } \\
\text { to public debates, expertise }\end{array}$ \\
\hline $\begin{array}{l}\text { 4.3. The experimental } \\
\text { reactor, "global } \\
\text { breakthrough" }\end{array}$ & $\begin{array}{l}\text { 4.5. Not approved technologies } \\
\text { without calculated risks, haste in } \\
\text { implementing the project }\end{array}$ \\
\hline 4.4. "Foolproof" & $\begin{array}{l}\text { 4.6. Human factor, lack of } \\
\text { control, violation of technology }\end{array}$ \\
\hline
\end{tabular}

In 2015, a series of statements, which are based on the "eco centric position" is not articulated in the public space (1.2., 3.1., 4.1, 4.3, 4.6.). Currently, as experts forming the field of public debate, greater importance is obtained by the representatives of the authorities and management of energy companies that are building the industry in accordance with the ideology of certain interests, given a vector of risk perception of other social actors. Like any ideology, it is full of myths, i.e. judgments which are the subject of faith, but not rational knowledge.

We will consider some of them, as well as methods of argument positions of social actors.

On the basis of the conducted analysis five ways of the argument of a position of these subjects were allocated: economic, political, ecological, technological and scientific.

Economic arguments are dominating today. "There are three imperatives: safety, ecological acceptability, economic efficiency. We have the only question - will it be cost effective?".

Development of the nuclear industry projects is a source of "attraction of taxes to the regional budget" that is followed by positive expectations concerning other spheres of social and economic development. So, it is "employment of highly skilled labor" as well as a "decrease in social tension", "development of social infrastructure", "solution of an energy problem", and "development of other power-consuming industries".

At first sight, economic benefits are obvious. However it is possible to see some kind of substitution of 
concepts. For example, the myth about highly skilled labor brings new potential risks: the facts are that 10 years later, the plant considerably decreased the production; there was an essential reduction of the personnel. Also new technologies are introduced today with which the personnel that quite early got under reduction has no experience. Moreover, costs of training of the personnel, approbation, start, elimination of consequences of implementation of new projects can level a potential economic effect. "There is a risk anyway, only risk of that? Risk that it will not work?"

Political arguments are focused round the idea of the leading region in the field of nuclear technologies. The argument reducing the importance of ecological initiatives sounds: "on a wave of Chernobyl many made the political capital", "shouters", "[concerning the environmental risks and consequences of accidents] we have not met the reasoned position yet".

Among the environmental arguments the most powerful are judgments about the "safety" of new technologies: "[about accidents] the equipment always worked properly", "influenced by the human factor". The selectivity of the choice of topics for discussion shows the importance of the events of the future: reactors on fast neurons are positioned as the leading technology and they are "completely safe". While the events of the recent past emerge in reasoning as a minor and insignificant question, not relevant at the moment: "and there was a concealment of danger, and danger puttying, and various processing methods on dilution of waste". Now we hear the declaration: "we will prove the absence of environmental risks by this project." If you consider that "absolutely safe" technology is still not implemented and not tested in practice, the mythological message of these judgments becomes clear.

The scientific arguments are focused around the fact that the "breakthrough" or "forward-looking" technologies that will be introduced at the enterprise may be a source of growth of scientific knowledge and in the future - of technology exports. In addition, from the perspective of the respondents, testing of new nuclear technologies (experimental site) also has a positive effect on science.

Identity and roles of social actors in safety issues. Supporters of a "technocentrism position" define themselves in the categories of "experts", "specialists", their opinion is "reasoned", "it is about facts and not about emotions". They use various names to reduce the opponents' importance (exaggeration, negative connotations): "screamers", "like that Baba Yaga from the cartoon". The advocates of the opposite position either identify themselves as "environmentalists" or refrain from making any nominations. Thus statements often have a subjectless character, for example, "the production activity of SCP is followed by formation of a large number of liquid, solid and gas-aerosol waste".

Despite the rational argument of a position, absence of the responsible agent reduces the trust degree to the statements and possibility of supporters mobilization. Images of opponents are designed by means of the following nominations: "officials", "managers", "so- called experts" who seek to "break to the budget" and "master investments".

Thus, there is a negative self-identity of supporters of an "environment oriented" position: "non-officials", "not managers", an identity that is on the contrary, unacceptable, frightening. It becomes an obstacle for formation of the active subject of the action who can defend the group interests.

The understanding of the role of experts seems logical "the goal is simple: to bring to the masses, let us call them so, objective information on radiation safety, the benefits of these industries for the region, for the city, for them personally."

An extreme option of the "technocentric" position: "Yes, it is necessary to talk less! Right. Because earlier people lived peacefully, what has changed since then? Nothing. There was a closed secret city, no one could get in, people worked and worked, and life went on as usual, everyone was happy, everything was fine." Thus, the social order is preserved, the number of arguments and access to new knowledge is limited.

Also today's position of ecologists is considered as interesting. Earlier in the debate ecologists acted as opponents of nuclear energy, but now a high level of social acceptability of nuclear power is demonstrated. Their role is to reduce the risks. "People who live in the nuclear cities and towns around the nuclear power plants must correctly understand these threats and we must correctly explain all to them"; "there has to be a possibility of carrying out public examinations"; "the state or corporation must compensate for this risk."

The peripheral activity of social movements, which could potentially increase the division of opinions, is insignificant in the region.

Studies conducted in Tomsk region, suggest that different groups of the population is characterized by a low degree of involvement in voluntary associations. [7] This means that the real competition of ideas and positions will gradually be lost.

On the one hand, autonomy of society, isolation on the problems of survival prevent the manifestation of activity in the realization of group interests. On the other hand, representatives of executive and legislative authorities are not interested in the revitalization of the public sector in the debate on nuclear issues.

Thus, in the 90 s of the last century it was possible to talk about an aggravated perception of risk, and the ecologists were the key actors of influence [8]. Today there is a shift of balance toward the "technocentric" position, review of the role of ecologists in the implementation of nuclear power projects.

Earlier environmental arguments concerned the security of the whole process of nuclear production, but at the present time it is possible to record transfer of emphasis in the rhetoric on security of the individual stage in the production cycle, "optimization of safety requirements."

Thus, among the ecologists "transportation safety of dangerous goods", "insurance against accidents", etc. are articulated. Arguments of ecologists become of little significance. In the regional press (2013) it is printed: "To the most zealous ecologists public men it was 
declared that their voice does not matter because the legislation allows making decisions of this sort without bringing the question to a vote" [9].

\section{Conclusion}

The 2015-year study has shown that the positions of the representatives of the most influential actors come closer, and ecologically-minded representatives soften their arguments and do not identify themselves as opponents ("I'm not an opponent of nuclear energy").

Based on the research we can state a gradual departure from the "ecology-centered" concept of risk in the direction of the influence of economic arguments to a limited audience.

The tendency of perception shows a shift towards artificially lowering of the importance of risks, increase of their social acceptability. It occurs against weak knowledge and passivity of the public sector, as illustrated by the data of our previous studies.

Thus, the rhetoric of opinion leaders shifts towards a "hierarchical" model of ideology (M. Douglas and A. Wildavsky) of nuclear energy. In this context, the social projects carried out by administrative means, and the activity "from below" are blocked by broadcast onesided information.

\section{References}

1. M. Douglas, A. Wildavsky, Risk and Culture (Berkley and Los Angeles: Univ. of California Press 1982)

2. V. Burr, An introduction to social constructionism (London, Routledge, 1995)

3. M. Jorgensen \& L. Phillips, Discourse analysis as theory and method (London, Thousand Oaks, New Delhi SAGE Publications, 2002)

4. N.V.Popravko, http://old.duma.tomsk.ru/page/7526/

5. L.S. Guryeva, Risk $i$ pravo naseleniya na ekologicheskuyu bezopasnost: vliyaniye yadernogo proizvodstva na teritorii Tomskoy oblasti. [Risk and the public's right to environmental security: the impact of nuclear facilities on the territory of the Tomsk region] (Tomsk, TSU Publishing house, 1997)

6. V. Kashpur, S. Afanasieva, S. Negrul, S. Kirpotin, Int. J. Environ. Stud. 72 (3), 592-598 (2015)

7. V.V. Kashpur, S.V. Negrul, Bulletin of the TSU, Philosophy. Sociology. Political science. 1(17), 129140 (2012)

8. L.V. Zemtsova, V.A. Zemtsov, 8th Korea-Russia International Symposium on Science and Technology - Proceedings: KORUS, 1, 367-369 (2004)

9. Obshchestvenniye slushaniya po sozdaniyu konversionnogo proizvodstva na OAO "Sibirskiy Khimicheskiy Kombinat" [Public hearings on the creation of the conversion of production at JSC "Siberian Chemical Combine"] // http://referendum.tomsk.ru/topic.phtml?id=2252\&vi $\underline{\text { ew}=\text { news }}$ 